\title{
Index to Volume 32, 2016
}

\author{
Contents of Volume 32, Numbers 1-4
}

Articles, see Author Index

Book Reviews 257, 541, 545, 1011, 1015

Editorial Collaborators 1019

Index 1025

Preface 787

\section{Author Index}

Al Baghal, T., See Belli, R.F.

Andreasch M. and Lindner, P. Micro- and Macrodata: a Comparison of the Household

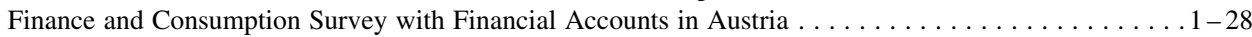

Baffour, B., Haynes, M., Western, M., Pennay, D., Misson, S., and Martinez, A. Weighting

Strategies for Combining Data from Dual-Frame Telephone Surveys: Emerging Evidence

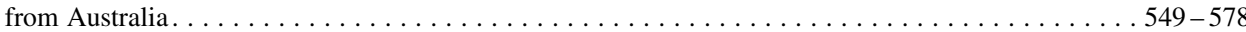

Ball, C., See Dunstan, K.

Barash V.D., Cameron, C.J., Spiller, M.W., and Heckathorn, D.D. Respondent-Driven Sampling

- Testing Assumptions: Sampling with Replacement . . . . . . . . . . . . . . . . . . . . . 29-73

Belli, R.F., Miller, L.D., Al Baghal, T., and Soh, L.-K. Using Data Mining to Predict the Occurrence

of Respondent Retrieval Strategies in Calendar Interviewing: The Quality of Retrospective

Reports . . . . . . . . . . . . . . . . . . . . . . . . . . . . . . . . 579-600

Belloni, M. Brugiavini, A., Meschi, E. and Tijdens K. Measuring and Detecting Errors in

Occupational Coding: an Analysis of SHARE Data . . . . . . . . . . . . . . . . . . . . . . . . 917-945

Beresovsky, V., See He, Y.

Boonstra, H.J., See Krieg, S.

Britton, T., See Malmros, J.

Brugiavini, A., See Belloni M.

Brust, O.A., Häder, S., and Häder, M. Is the Short Version of the Big Five Inventory (BFI-S)

Applicable for Use in Telephone Surveys? . . . . . . . . . . . . . . . . . . . . . . . . . . . . 601-618

Burger, J., See Vand Delden, A.

Burke, Ó., See Nguyen, N.D.

Cameron, C.J., See Barash, V.D.

Chen, H., See Zhang, N.

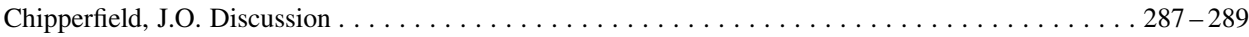

Coelho, P.S., See Dias, C.A.

Coleman, Y. S. Data-Mining Opportunities for Small and Medium Enterprises with Official

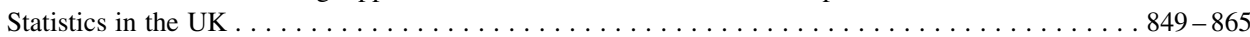

Conrad, F.G., Couper, M.P., and Sakshaug, J.W. Classifying Open-Ended Reports: Factors

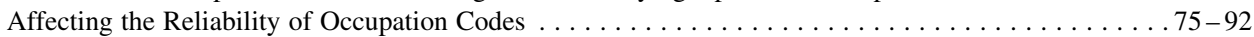

Couper, M.P., See Conrad, F.G.

Dalla Valle, L. The Use of Official Statistics in Self-Selection Bias Modeling . . . . . . . . . . . 887-905

De Fátima Salgueiro, M., See De Toledo Vieira, M.

De Haas, S., and Winker, P. Detecting Fraudulent Interviewers by Improved Clustering Methods

- The Case of Falsifications of Answers to Parts of a Questionnaire . . . . . . . . . . . . . . . . . . . 643-660

De Toledo Vieira, M., Smith P.W.F., and De Fátima Salgueiro, M. Misspecification Effects in the

Analysis of Panel Data. . . . . . . . . . . . . . . . . . . . . . . . . . . . . . . . . . . . . 487-505 
Deutsch, T. Statistical Capacity Building of Official Statisticians in Practice: Case of

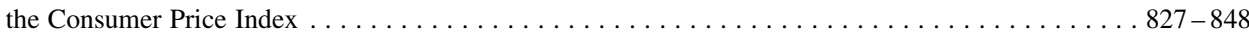

Dias C.A., Wallgren, A., Wallgren, B., and Coelho, P.S. Census Model Transition: Contributions

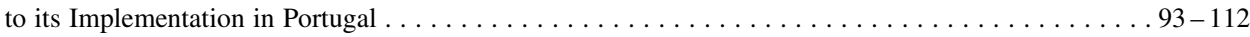

Diersch, N. and Walther, E. The Impact of Question Format, Context, and Content on Survey

Answers in Early and Late Adolescence . . . . . . . . . . . . . . . . . . . . . . . . . . . 307-328

De Smedt, M. Special Section: Invited Commentary - Addressing the Needs of Official Statistics

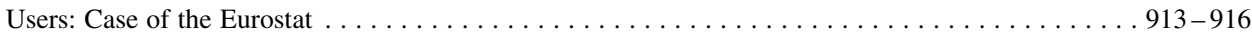

Dolson, D., Discussion. . . . . . . . . . . . . . . . . . . . . . . . . . . . . . . . . . . . . . . . . . 291-294

Dong, H. and Meeden, G. Constructing Synthetic Samples . . . . . . . . . . . . . . . . . . . . 113 - 127

Dunstan, K., and Ball, C. Demographic Projections: User and Producer Experiences of

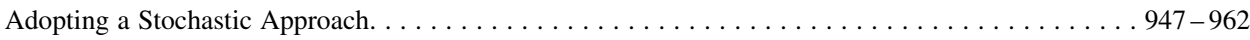

Elliot, M., Mackey, E., O’Shea, S., Tudor, C., and Spicer, K. End User Licence to Open

Government Data? A Simulated Penetration Attack on Two Social Survey Datasets . . . . . . . . . 329-348

Elliott, M.R., See Zhang, N.

Elliott, M.R., See Zhou, H.

Elliott, M.R., See Xia, X.

Eltinge, J.L. Discussion . . . . . . . . . . . . . . . . . . . . . . . . . . . . . . . . . . 295-300

Forbes, S. and Keegan A. Helping Raise the Official Statistics Capability of Government

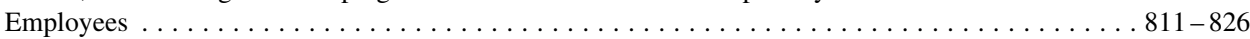

Gonzalez, J.M., Discussion . . . . . . . . . . . . . . . . . . . . . . . . . . . . . . . . . . . . . . . . . . $295-300$

Haziza, D. and Lesage, É. A Discussion of Weighting Procedures for Unit Nonresponse . . . . . . . 129-145

Haynes, M, See Baffour, B.

He Y., Shimizu, I., Schappert, S., Xu, J., Beresovsky, V., Khan, D., Valverde, R., and Schenker, N.

A Note on the Effect of Data Clustering on the Multiple-Imputation Variance Estimator:

A Theoretical Addendum to the Lewis et al. article in JOS $2014 \ldots \ldots \ldots \ldots \ldots$. . . . . . . . . . . $147-164$

Heckathorn D.D., See Barash V.D.

Hobza, T., and Morales, D. Empirical Best Prediction under Unit-Level Logit Mixed Models . . . . 661-692

Häder, M., See Brust, O.A.

Häder, S., See Brust, O.A.

Ioannidis. E., Merkouris, T., Zhang, L.-C., Karlberg, M., Petrakos, M., Reis, F., and Stavropoulos, P.

On a Modular Approach to the Design of Integrated Social Surveys . . . . . . . . . . . . . . 259-286

Ioannidis. E., Merkouris, T., Zhang, L.-C., Karlberg, M., Petrakos, M., Reis, F., and

Stavropoulos, P. Rejoinder. . . . . . . . . . . . . . . . . . . . . . . . . . . . . . . . . 301-305

Josten, M. and Trappmann, M. Interviewer Effects on a Network-Size Filter Question . . . . . . . . . 349-373

Karlberg, M., See Ioannidis, E.

Karlberg, M., See Ioannidis, E. Rejoinder

Keegan, A., See Forbes S.

Kenett, R.S. and Shmueli, G. From Quality to Information Quality in Official Statistics . . . . . . . 867-885

Khan, D., See He, Y.

Krieg, S., Boonstra H.J., and Smeets M. Small-Area Estimation with Zero-Inflated Data -

A Simulation Study . . . . . . . . . . . . . . . . . . . . . . . . . . . . . . . . . $963-986$

Krsinich, F. The FEWS Index: Fixed Effects with a Window Splice . . . . . . . . . . . . . . . . . . . $375-404$

Körner, T., and Wolff , L. "Do the Germans Really Work Six Weeks More than the French?"

- Measuring Working Time with the Labour Force Survey in France and Germany. . . . . . . . . . 405 - 431

Lesage, É., See Haziza, D.

Lindner, P., See Andreasch, M.

Lipps, O. and Pekari, N. Sample Representation and Substantive Outcomes Using Web With and

Without Incentives Compared to Telephone in an Election Survey. . . . . . . . . . . . . . 165-186

MacFeely, S. The Continuing Evolution of Official Statistics: Some Challenges and Opportunities . . 789-810

Mackey, E., See Elliot, M.

Malmros, J., Masuda, N., and Britton, T. Random Walks on Directed Networks: Inference and

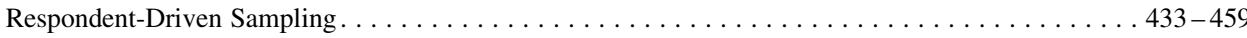

Martinez, A., See Baffour, B.

Masuda, N., See Malmros, J.

Meeden, G., See Dong, H.

Merkouris, T., See Ioannidis, E.

Merkouris, T., See Ioannidis, E. Rejoinder 
Meschi, E., See Belloni M.

Miller, L.D., See Belli, R.F.

Misson, S., See Baffour, B.

Morales, D. See Hobza, T.

Moura, Fernando A.S., See Souza, D.F.

Murphy, P., See Nguyen, N.D.

Nandram, B. Bayesian Predictive Inference of a Proportion Under a Twofold Small-Area Model . . 187-208

Nguyen, N.D., Burke, Ó., and Murphy, P. A Simulation Study of Weighting Methods to

Improve Labour-Force Estimates of Immigrants in Ireland . . . . . . . . . . . . . . . . . . . . . . . . 693-718

Nilsson, P. An Imputation Model for Dropouts in Unemployment Data . . . . . . . . . . . . . . . . $719-732$

Norberg, A. SELEKT - A Generic Tool for Selective Editing . . . . . . . . . . . . . . . . . . . . . . 209-229

Ograjenek, I. Editorial - Special Section on The Role of Official Statistics in Statistical

Capacity Building . . . . . . . . . . . . . . . . . . . . . . . . . . . . . . . . . . 787-788

Ogwang, T. The Marginal Effects in Subgroup Decomposition of the Gini Index . . . . . . . . . . . . 733 - 745

O'Shea, S., See Elliot, M.

Pascale, J. Modernizing a Major Federal Government Survey: A Review of the Redesign of the

Current Population Survey Health Insurance Questions . . . . . . . . . . . . . . . . . . 4 461-486

Pekari, N., See Lipps, O.

Pennay, D., See Baffour, B.

Petrakos, M., See Ioannidis, E.

Petrakos, M., See Ioannidis, E. Rejoinder

Pullinger, J. Special Section: Invited Commentary - The Role of Official Statistics in Statistical

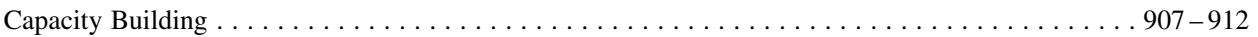

Raghunathan, T.E., See Zhou, H.

Reis, F., See Ioannidis, E.

Reis, F., See Ioannidis, E. Rejoinder

Sakshaug J.W, See Condrad F.G.

Schappert, S., See He, Y.

Schenker, N., See He, Y.

Scholtus, S., See Van Delden. A.

Shimizu, I., See He, Y.

Shmueli, G., See Kenett, R.S.

Smeets, M., See Krieg, S.

Smith P.W.F., See De Toledo Vieira, M.

Soh, L.-K., See Belli, R.F.

Souza, D.F., Moura Fernando A.S. Multivariate Beta Regression with Application in Small

Area Estimation. $747-768$

Spicer, K., See Elliot, M.

Spiller M.W, See Barash V.D.

Stavropoulos, P., See Ioannidis, E.

Stavropoulos, P., See Ioannidis, E. Rejoinder

Tijdens, K., See Belloni, M.

Trappmann, M., See Josten, M.

Tudor, C., See Elliot, M.

Wallgren, A., See Dias, C.A.

Wallgren, B., See Dias, C.A.

Walther, E., See Diersch, N.

Van Delden, A., Scholtus, S., and Burger J. Accuracy of Mixed-Source Statistics as Affected

by Classification Errors . . . . . . . . . . . . . . . . . . . . . . . . . . . . . . . . . . . . . . . . . . . . 619-642

Watson, N. Dead or Alive? Dealing with Unknown Eligibility in Longitudinal Surveys . . . . . . . 987 - 1010

Western, M., See Baffour, B.

Winker, P., See De Haas, S.

Wolff, L., See Körner, T.

Valverde, R., See He, Y.

Xia, X. and Elliott, M.R. Weight Smoothing for Generalized Linear Models Using a Laplace Prior. . 507-539

$\mathrm{Xu}, \mathrm{J}$., See He, Y.

Zhang, L.-C., See Ioannidis, E.

Zhang, L.-C., See Ioannidis, E. Rejoinder. 
Zhang, N., Chen, H., and Elliott, M.R. Nonrespondent Subsample Multiple Imputation in

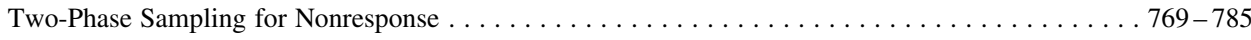

Zhou, H., Elliott, M.R., and Raghunathan, T.E. Synthetic Multiple-Imputation Procedure for

Multistage Complex Samples. $.231-256$

\section{Book Reviews}

Constructing Survey Data: An Interactional Approach

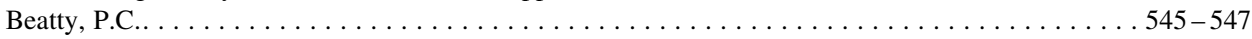

Web Survey Methodology

Herzing, Jessica M.E. . . . . . . . . . . . . . . . . . . . . . . . . . . . . . . . . . . . . . . . . . 1011-1014

Past, Present, and Future of Statistical Science

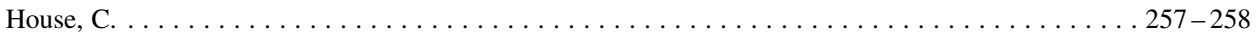

Improving Survey Methods: Lessons from Recent Research

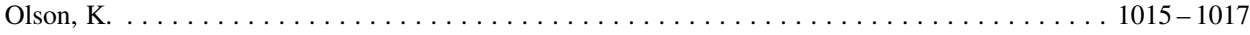

Designing and Conducting Business Surveys

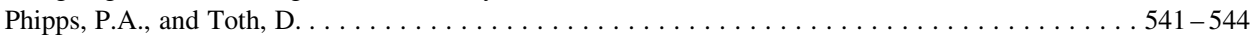

